\title{
INTERACTIONS BETWEEN LEGAL SYSTEMS IN THE JUDICIAL PROCESS OF KENDENG CASE (A CRITICAL ANALYSIS OF ACCESS TO JUSTICE)
}

\author{
Wahyu Nugroho \\ Doctoral Programme Faculty of Law Padjadjaran University \\ wahyulaw86@yahoo.com
}

\begin{abstract}
The Indonesian state has the characteristic of legal system plurality in a national legal system, it is interesting to be observed from law making, licencing, law implementation, to judiciary process. State organizers in the context of government (executive power) as the licensors of business activities and the judiciary (judicial power) State Administration, as absolute competence over the objects of environmental administration disputes require optical and comprehensive holistic understanding, amidst the very diverse conditions of the legal system (legal pluralism) and a pluralistic society to be bound in a single national legal system (unification). The problem formulation in this paper is: (1) How is the interaction of continental European legal system and customary law system on kendeng case in the tiered judicial process? And (2) how does the interaction affect the legal system on the judge's mindset over environmental permit disputes objects? In relation to executive power as a licensor, the involvement of the public in the process of publishing environmental documents becomes a very important matter. Kendeng Community of Rembang Regency Central Java Province is fighting for its rights and various access to justice, finally choosing the judicial route as the main tool against the state, namely the State Administrative Court (PTUN) Semarang, High Administrative Court (PT $T U N)$ Surabaya, Until the most recent legal remedy in the judicial system in Indonesia, namely the Review Supreme of Court. In this paper, it shows the interaction between the legal system, the continental European legal system and the customary law system in the process of tiered justice as an access to justice for the kendeng mountain community.
\end{abstract}

Keywords: legal system, judge, kendeng, environmental permissions, State Administrative Court (PTUN)

\section{Introduction}

Basically the legal systems in the world are divided into two groups, i.e., the European Continental legal system ${ }^{1}$ and the Anglo-Saxon legal system ${ }^{2}$. As a result of the Dutch colonization, Indonesia adopts the legal system prevailing in the Continent, or Romano-Germanic legal system, or civil law system. In the book Ilmu Hukum (Legal Sciences), by referring to David \& Brierly, Satjipta Rahardjo defines the term of civil law system as a Romano-Germanic legal

\footnotetext{
${ }^{1}$ John Gilisen and Emeritus Gorle Frits. (2005). History of Law An Introduction. (Bandung :Refika Aditama).

2 Ade Maman Suherman. (2004). Introduction to the Comparison of Legal Systems. (Jakarta : Rajagrafindo Persada).
} 
system, because this name reflects the substance and history contained in it ${ }^{3}$. Indonesia as a plural state by directing it toward one national legal system (unification) at the operational practical level starting from the policy, the application of law until the judicial process, has induced the interactions between legal systems, i.e. European Continental, Anglo-Saxon, and common law and Islamic law legal systems.

In a constitutional state, the law must be understood and developed as one system unit. As a system, law consists of these elements: (i) institution, (ii) rules of law (instrumental), and (iii) behaviors of the subjects of law who take up the rights and obligations determined by the norms of such rules (subjects and cultural). These three elements of legal system comprise such activities as: (a) law making, (b) law administrating, and (c) law adjudicating or normally referred to as law enforcement in a limited sense. In addition to such activities, there are other activities that are often neglected, i.e., (d) extensive law socialization and education, and also (e) law information management ${ }^{4}$.

In the perspective of Lawrence M. Friedman, law is a system that consists of structure, substance and legal culture components. Structure is the institutions of law enforcement, including law making. A judicial system, for instance, comes on mind when speaking about the number of judges, court jurisprudence, how the higher court stands above the lower court and the persons related to various kinds of court. On the other hand, the substance is composed of rules and regulations on how such institutions should behave themselves. The structure and substance of law will be in motion if there are legal culture elements, i.e., social attitude and values elements. The legal culture refers to the parts existing in the customary general culture, opinion, way of behaving and thinking that direct the social forces toward or away from the law in certain manners.

One of the legal philosophies that has a great influence on the Indonesian national law, whether in the past or at present, is the philosophy of von Savigny, which is applied by the common law experts. However, coincident with this legal philosophy the freedom fighters were also

\footnotetext{
${ }^{3}$ Satjipto Rahardjo, (2000). Legal Sciences, (5th Ed). (Bandung : Citra Aditya Bakti).
}

${ }^{4}$ Jimly Asshiddiqie . (2005). "The Implication of Amendment to the 1945 Constitution in the Development of National Law)" Speech at the Opening of Seminar on the Study of National Law) (SPHN) 2005, held by the Indonesia's National Law Commission (KHN). Jakarta on November 21. 
fascinated with the influence of Napoleon's Code, causing the legism philosophy to become strong as well. The law is regarded as comprising the laws and legislations only ${ }^{5}$. Therefore, when talking about the law, the idea in mind is immediately directed to the drafting of bills or the enforcement of legislations only. This is different from England or America which also frequently refers it onesidedly to judiciaries and their jurisprudence as though there is no law beyond the case law. As a system, the law consists of a number of interrelated elements or components that are influential on each other, or of several principles ${ }^{6}$. Sistemically, the system of Indonesian nasional bases itself on Pancasila (Five Principles of the State) and the 1945 Constitution and the amendments, in which every aspect of law that constitutes part of the system of national law must be based on Pancasila and the 1945 Constitution as its source.

The environmental law as a system has a legal function, i.e., to realize the purpose of protecting the developed environment based on various agreements and international treaties, the aspects and the awareness of the environmental protection significance in the perspective of national law. Daud Silalahi considers that the inclusion of an environmental aspect in the law making process is imperative for ecodevelopment conception and consistent with the principles agreed upon in numerous international conferences ${ }^{7}$. The concerns over environmental matters and legal arrangements develop rapidly in line with economic development in which the advancement of technology that has a role in promoting the natural resources management sector is taken into consideration when the natural resources management has an adverse impact on the environment ${ }^{8}$.

Indonesia, which has a characteristic of legal system plurality in one national legal system, is interesting to study, starting from the law making, licensing, law implementing, until the judicial

\footnotetext{
${ }^{5}$ Sunaryati Hartono. (1991). Legal Policy Toward One National Legal System, (1st Ed). (Bandung :Alumni).

${ }^{6}$ Lili Rasjid and I.B. Wyasa Putra.( 2003). Law as a System, (2nd Ed). (Bandung :Mandar Maju).

${ }^{7}$ Daud Silalahi, in Amiruddin A. Dajaan Imami, et. al. (2013). The Development of Environmental Law Today and In The Future. (Bandung : Department of Legal and Social Development in cooperation with Logoz Publishing)

${ }^{8}$ Maret Priyanta. (2017). Continuous Forest Management as Part of Environmental Law System Restoration and Season Cycle-Based Space Layout, Doctor's Degree Program in Legal Sciences, the Faculty of Law, Pajajaran University, Bandung, Dissertation.
} 
process. The state administration in the government context (executive power), as the provider of business licenses, and the administrative courts (judicative power) as the absolute competence of the object of environmental administration dispute, needs some optic and holistic-comprehensive understanding amidst the legal pluralism circumstances as well as the plural community, to be bounded in one national legal system (unification) ${ }^{9}$. With regard to the executive power, as the provider of licenses, the people involvement in the process of issuance of environmental documents becomes an important matter. If the government ignores the people involvement in the issuance of environmental documents through the Ruling of the Administrative Officials, such ignorance has potensial filing of a lawsuit with the Administrative Court (PTUN).

The legal relation between the state, investors and the surrounding community in principle or at an ideal level creates a balance of interest, without domination and competition against each other Jimly Asshiddiqie, 2013). When a conflict takes place, however, whether vertical or horizontal, the people living around the business premises adopt various methods to have access to justice collectively, in Indonesia, in the utilization of natural resources ${ }^{10}$. Such various methods are, among others, a mass advocacy movement and publication in the mass media, environmental campaign, environmental and natural resources mediation, the occupation of buildings of the policy making institutions through demonstrations by giving theatrical presentations, the filing of a claim for compensations against entrepreneurs, the use of political channels with pressure to several members of the legislative body as the people's representatives as well as of formal procedure channels through the court. Some of these techniques depend largely on the strength of the groups of people under their control and on the confidence that such techniques will bring in justice. In the context of farmers community in Kendeng (the highlands in the north-eastern part of Central Java), almost all efforts have been made, both litigations and non-litigations (mass-advocacy and demonstrations,

\footnotetext{
${ }^{9}$ Ida Nurlinda.(2014). Monograph of Agrarian Law. Developing Legal Pluralism for the Unification of Agrarian Law, (1st Ed). (Bandung: Center for the Study of Environmental Law and Space Layout, The Faculty of Law, Pajajaran University \& Logoz Publishing.)

${ }^{10}$ Bedner, Adriaan. (2011). Preface: Access to Justice and the Handling of Environmental Issues, (The Struggle of Poor and Unlucky People to Claim their Rights in Indonesia), (1st Ed). (Jakarta HuMa KITLV Epistema Institute; Leiden: Van Vollenhoven Institute).
} 
publication of legal issues in the mass-media, political pressure to the members of the House of Representatives and the mass-occupation of government institution buildings by holding theatrical demonstrations).

The Kendeng case as set out in Decision of the Court of Review (Supreme Court) No. 99 PK/TUN/2016 is interesting to study and a good example of access to justice in Indonesia on the issuance of an environmental license in developing the study of environmental law and administrative law, especially on the General Principles of Good Governance (AUPB). The Kendeng farmers community of Rembang Regency, Central Java province, in struggling for their rights and access to justice finally choose a court of law as the main instrument to oppose the state, i.e. the Administrative Court of Semarang, and the Administrative Court of Surabaya, and a remedy of the last resort in Indonesian judiciary, i.e., the Supreme Court Review. This hierarchical judicial process indicates an interaction between legal systems, i.e., the European Continental law (civil law) and the common law, as an effort to have access to justice.

\section{Method}

This research uses empirical juridical, and supported by normative data sourced from legislation and court decisions. Qualitative juridical descriptive analysis and data collection techniques using literature.

\section{Result And Discussion}

\subsection{Access to justice through interactions between European Continental and common law legal systems on Kendeng case in the judicial process}

One of the characteristics of a law state as asserted by Jimly Asshiddiqie is that it has an Administrative Judiciary ${ }^{11}$. As a legal system institution, the function of the Administrative

${ }^{11}$ Jimly Asshiddiqie. (2012).Constitutional Law \& Pillars of Democracy, (2nd Ed). (Jakarta :Sinar Grafika). 
Judiciary is to serve as bridge for the state interests and the community interests. The object of dispute over the decision of Administrative Court officials in this case is the environmental license, which is related to other environmental documents (AMDAL and UKL-UPL). The European Continental legal system with a legislation characteristic and a certainty of law intention has influenced the judges in the Administrative Court who served as a trumpet/ mouthpiece of laws only (legism concept). However, there are interests of the general public that are represented by Kendeng farmers group or customary community who uphold the common law legal system that has been prevailing from generation to generation.

The state's control of natural resources as mandated by the constitution stated in this study is carried out by making policies on environment in the mining sector. A mining business activity cannot be separated from the social context of the surrounding environment, starting from the creation of regulations, the acquirement of some environmental licensing instruments, the implementation, supervision, control, until the settlement of environmental conflicts in the mining area. The stakeholders who have a role, i.e., the central and/ the local governments, the entrepreneurs and the local people have different view of mining as related to social justice and environment. Starting from the formulation of regulations at the local level (local government laws), the preparation of licenses, until the performance of mining activities, the state law and the common law interact with each other, having influences on one another.

Refer to Von Savigny, that legal system is reflection of the soul of the people who develop the law, and law derived from custom and beliefs and not derived from founding act ${ }^{12}$.This can be seen in the Kendeng farmer's which had their own thingking about the law, society.

The interaction between legal systems can occur because of the diversity of law in a certain territory of a country or is better known as legal pluralism ${ }^{13}$, starting from the creation of regulations until their implementation. A study on legal pluralism in a country mostly relates to a natural resources issue which intersects the environment, land use and space layout. During the process of interaction between the state law and the local law, in the implementation, conflicts often arise over the utilization of natural resources, especially in the mining sector.

\footnotetext{
${ }^{12}$ Siti Malikhatun Badriyah. "Justice a Yearning In the Implementation of the Contract in the Society". Diponegoro Law Review. Vol 2. No. 1 .April 2017, pp 154 - 167.

${ }^{13}$ Myrna A. Savitri et. al. (2011). What is Legal Pluralism for? Negotiation Concept in Agrarian Conflicts in Indonesia. (1st Ed). (Jakarta : Epistema Institute-HuMA-Forest People's Programme.).
} 
Under the law interaction concept according to Moores as cited by Ade Saptomo ${ }^{14}$, when the state law and the common law interact in one social field, five possibilities will presumably arise: first, integration, namely, the fusion between part of the state law and the common law or any other similar law, second, incorporation, namely, adapting part of the state law to the common law or vice versa, third, conflict, namely, there is no fusion at all since the state law and the common law are contradictory to each other, fourth, competition, namely, the state law, the common law and other law run separately in the access to natural resources, and fifth, avoidance, namely, one law avoids the operation of the other law. The occurrence of law interactions is the prominent characteristic of a legal pluralism study, and in the empirical fact one of them will potentially become weaker, and on the contrary the other will be stronger (weak and strong legal pluralism).

\subsection{The influence of legal system characteristic on the judge's way of thinking in the object of environmental license dispute}

The development of the world legal systems have influences on the law enforcement system in a country, especially the role of judges in the judicial process. A case of environment (emphasizing the administrative aspect) is very complex as it relates to non-legal factors (ranging from economic, social, cultural, environmental to ethical factors). In this context, environmental law is one of those which falls within the field of study and goes along with the social development and may not be forced to adhere to the 19th century thoughts that "idolize" legal positivism as an implication of the civil law system application. Through Capra deep ecology, in the 21 st century, given the complexity of environmental issues (judicial process) the judge's optics should have been of "dragonfly" eyes that are able to view various aspects, i.e., organism, social system, and ecology ${ }^{15}$. Such an argument was found in the case of cement mining conflict between the people of Kendeng highlands of Rembang Regency, Central Java, versus Central Java Governor and PT. Semen Indonesia, Tbk (Persero).

\footnotetext{
14 Ade Saptomo.(2010). Law and Local Wisdom, Revitalization of Indonesian Customary Law. (Jakarta :PT. Gramedia Widiasarana Indonesia).

${ }^{15}$ Wahyu Nugroho. Aspect of Legal Sociology in the Enforcement of Environmental Law. (1st Ed), Yogyakarta .Genta Press.
} 
The Administrative Court judges used the General Principles of Good Governance (AUPB) as the basis for examining, reviewing and rendering considerations with some legal interpretations in their possession. One of the general principles of good governance is the principle of people participation, which is extremely crucial because it involves the social and environmental impacts on the surrounding people after the issuance of the Administrative Court decision, which is in this context the environmental license instruments, i.e. the Environmental Impact Analysis (AMDAL) document and the environmental license. This document from the inception requires the participation of the community in order to accommodate the interests of the surrounding people, including the existence of multiplier effects and business activities.

Kendeng people together with the team of the Ministry of Environment (KLH) on July 2014 made a site visit to the Watuputh groundwater basin area in Gunem District, Rembang Regency. During the visit the people found one ponor point (swallow hole) located at the Mining Business License (IUP) area of PT. Semen Indonesia (Persero), Tbk. Another visit was made on August 12, 2013 and a ponor point was also found. Such processes/discoveries were not known by the people, while the Mining Business License (IUP) has been issued. In examining this case, the judges of the trial court and the appellate court did not look at the case holistically, whereas on the contrary the Judge in the Supreme Court review proceeding took a comprehensive look at it, either from the rule (material) side involving the object of environmental dispute or the procedure (formal) side for AMDAL documents and environmental license, and the finding of facts at the location of mining operated by PT. Semen Gresik.

Based on statutory regulations, actually there are spreading norms that address the participation of the people as umbrella lex in the context of environmental preservation and licensing matters, i.e., of Law No. 32/2003 on Environment Preservation and Management, which subsequently brings forth Government Regulation No. 27/2012 on Environmental License and finally descends again to Regulation of the State Minister for Environment of the Republic of Indonesia No. 17/2012 on the Guidelines for the Involvement of Community in the Process of Environmental Impact Analysis and Environmental License.

In point of fact, the friendly gathering that was held by the Deputy Regent of Rembang at the Meeting Hall of Gunem District on June 22, 2013 was not specially intended for the announcement or socialization of the environmental license, which was made based on the friendly gathering, the 
residents presence and the list of attendance only. The carrying out of such a friendly gathering was then used by the government, which was corroborated by the appellate court, as the basis for interpreting the people involvement and knowledge in accordance with the provisions on community participation in the above-stated statutory regulations. The people involvement should have been construed and interpreted as "starting from the preparation of the initial document until the issuance of the environmental license". The community involvement is part of the process of environmental license issuance through announcements and public consultations. It is appeared from a thorough examination of this case that the community involvement is only a frame and pretext in order to legitimize a business that is covered by a wrap in the form of environmental impact document and license. Although the people majority reject the business activity, such rejection does not prevent the Administrative Court official from issuing the documents.

The delay in the filing of lawsuit for the issuance of environmental license became the subject of debates between the judges and officials in each echelon of the Administrative Court. The time limit for the filing of lawsuit became the cause of dismissal decision. This time limit has in practice brought about separate interpretations and even debates among the judges from the Administrative Court to the Supreme Court. In the Court of First Instance, and corroborated in the appellate court, the Judge Panel only used as guidance the Article 55 of Law No. 5/1986 on Administrative Judiciary and disregarded Article 89 paragraf (1) of Law No. 32/2009 on Environmental Cultivation and Preservation (PPLH). Two environmental licensing instruments, namely, Environmental Impact Analysis and Environmental License under procedural rules failed to comply with the general principles of good governance and people participation, so it can be stated as a procedural default.

As regard to such a legal fact in the judicial process, B. Arief Sidharta from the point of law philosophy directs the argumentation toward a type that takes up legal sciences through a thinking process (reasoning) ${ }^{16}$ i.e., axiomatic (systemic) thinking and topical (problematic) thinking. Such guided legal science offers solutions to concrete legal problems, actual or potential. What one seeks in law is a solution in the frame of the applicable legal structure, which is in itself, up to a certain degree, already structured systematically, and ensures stability and predictability, so as to realize the

\footnotetext{
${ }^{16}$ Bernard Arief Sidharta. (2013).Indonesian Legal Science, an Effort to Develop a Systematic Legal Science that is Responsive to Social Changes. (1st Ed). (Yogyakarta : Genta Publishing).
} 
certainty of law and justice in the community. In relation to a legal objective, the idea to bring about a perfect system in legal structure, although it will never be achieved, assumes an important role, i.e., to function as a structuring principle. Based on the directive of Arief Sidharta above, it can be stated that the judges of the Administrative Court of First Instance and Court of Appeals in settling the dispute over the environmental license did not use a systemic thinking model, rather, they only used a problematic thinking model. On the other hand, the Judge in the Supreme Court review proceeding combined a problematic thinking model with a systemic thinking model. Actually at an ideal level the model of thinking in the juridical arguments or in legal sciences is the combination of problematic thinking and systemic thinking, or referred to as a systemized problematic thinking model.

As a state administration system, the legal structure plays a significant role both for the state administrators (Central Java Provincial Government and Rembang Regency Administration) and the judges of the trial and appellate courts in Kendeng case, who have limited understanding and misinterpretation as to the principle of community participation as a manifestation of the transparency principle which is part of the principles of good governance. This narrow understanding and misinterpretation are appeared from the lead time or the limit of delay for the filing of lawsuit by referring to Article 55 of Law No. 5/1986, i.e., ninety (90) days from the announcement of the decision on June 11, 2012. In fact, to the object of action against the Administrative Court on environment, Law No. 32 of 2009 and Circular of the Supreme Court (SEMA) No. 2 of 1991 section V item 3 should be applied, which essentially provides that the counting of the lawsuit filing is from the plaintiff's knowledge of the injury occurrence in the form of environmental pollution and damage. More astonishingly, Plaintiff I, whose name is Joko Prianto, during the event of friendly gathering on June 22, 2013 was considered as present in there, while in fact the person concerned was traveling by plane as proved by the ticket and boarding pass from Pontianak to Jakarta. It is on the basis of this last statement that the judicial review application was submitted and finally granted entirely by the Supreme Court, annulling the decision of the Administrative Higher Court No. 135/B/2015/PT.TUN/ SBY dated November 3, 2015 which corroborated the decision of the Administrative Court, Semarang, No. 064/G/2014/PTUN.SMG dated April 16, 2015, and declaring as void Decision of the Governor of Central Java No. 660.1/ 17 
of 2012 dated June 7, 2012 on the environmental license for mining operation by PT. Semen Gresik (Persero) Tbk. in Rembang Regency, Central Java Province.

The civil law system has been dominant in the administrative courts both in the executive power through policies and in the judicative power exercised by the judges. Paul Scholten, a Dutch legal thinker as cited by Satjipto Rahardjo ${ }^{17}$ points out that he has seen some changes in people's way of implementing the law and in their way of thinking. In the 19th century, people thought with full certainty, in which condition they used legal reasoning in the form of "hanteren van logische figuren" (utilization of logical figures) which means processing the law like doing mathematic work. Such changes in the way of thinking appeared obviously from the considerations of decisions rendered by the judges of the Administrative Court of First Instance and Court of Appeals on the case of environmental license lawsuit which harms the common law.

At last, in performing his duties in the court the judge must always adhere to the values developing in the community, including finding out the interests and existence of the common law community, as part of the common law system, which existence is recognized by the state and effectively in force in every region. Although the law and justice are an inseparable duumvirate, however, it might happen that a regulation does not contain any justice. For this reason, a judge must endeavor in such that the gap and discrepancy between the law and justice can be minimized, i.e., by exploring, following, and understanding the legal values prevailing in the community.

\section{Conclusions}

1. Access to justice for Kendeng customary community through interactions between the European Continental legal system and the common law legal system on Kendeng case is appeared in the judicial process starting from the Administrative Court of First Instance, the Court of Appeals until the Court of Review. It is obvious that the judges only used the statutory regulations in his considerations relating to the object of lawsuit, the delay in filing the lawsuit and the community participation in the process of issuance of the environmental license, while in the empirical facts around Kendeng highlands there is a common law society that has a separate local wisdom in managing and preserving the

\footnotetext{
${ }^{17}$ Satjipto Rahardjo.(2009). Stratum in Legal Study, (1st Ed), (Malang : Bayumedia Publishing).
} 
environment, the common law system, which has been planted from generation to generation in Kendeng community.

2. There was an influence from the interactions between the systems of law on the judge's way of thinking over the object of environmental license dispute, in which the judges of the trial and appellate courts in settling the dispute did not use a systemic thinking model, rather, they only used a problematic thinking model. On the other hand, the Judge in the Supreme Court review proceeding combined the problematic thinking model with the systemic thinking model.

\section{References}

Suherman, Ade Maman (2004). Introduction to the Comparison of Legal Systems. Jakarta: Rajagrafindo Persada.

Saptomo, Ade , (2010). Law and Local Wisdom, Revitalization of Indonesian Customary Law. Jakarta : PT. Gramedia Widiasarana Indonesia.

Bedner, Adriaan, (2011). Access to Justice and the Handling of Environmental Issues, (The Struggle of Poor and Unlucky People to Claim their Rights in Indonesia), (1st Ed). Jakarta: HuMa; KITLV-Jakarta; Epistema Institute; Leiden: Van Vollenhoven Institute

Sidharta, Bernard Arief, (2013). Indonesian Legal Science, an Effort to Develop a Systematic Legal Science that is Responsive to Social Changes). (1st Ed), (Yogyakarta :Genta Publishing).

Imami, Amiruddin A. Dajaan, et. al. (2013). The Development of Environmental Law Today and In The Future, (Bandung : of Legal and Social Development in cooperation with Logoz Publishing).

Gilisen, John and Emeritus Gorle Frits. (2005). History of Law, An Introduction, (Bandung : Refika Aditama).

Nurlinda. Ida , (2014). Monograph of Agrarian Law. Developing Legal Pluralism for the Unification of Agrarian Law, (1st Ed), (Bandung: Center for the Study of Environmental Law and Space Layout, The Faculty of Law, Pajajaran University \& Logoz Publishing) 
Asshiddiqie, Jimmly. (2012). Constitutional Law \& Pillars of Democracy, 2nd Ed. (Jakarta : Sinar Grafika) , (2005). "The Implication of Amendment to the 1945 Constitution in the Development of National Law)", Speech at the Opening of Seminar on the Study of National Law) (SPHN) 2005, held by the Indonesia's National Law Commission (KHN).

Putra, Lili Rasjid and I.B. Wyasa (2003). Law as a System, (2nd Ed), (Bandung :Mandar Maju) Priyanta, Maret, (2017). "Continuous Forest Management as Part of Environmental Law System Restoration and Season Cycle-Based Space Layout"Savitri, Doctor's Degree Program in Legal Sciences, the Faculty of Law, Pajajaran University, Bandung. Dissertation.

Savitri. Myrna A. et. al., (2011). What is Legal Pluralism for? Negotiation Concept in Agrarian Conflicts in Indonesia, 1st Ed. (Jakarta : Epistema Institute-HuMA-Forest People's Programme).

Rahardjo, Satjipto , (2000). Legal Sciences, (5th Ed), (Bandung: Citra Aditya Bakti).

---------, (2009). Stratum in Legal Study, (1st Ed), (Malang :Bayumedia Publishing).

Hartono. Sunaryati , (1991). Legal Policy Toward One National Legal System, (1st Ed), Bandung :Alumni)

Nugroho, Wahyu, Aspect of Legal Sociology in the Enforcement of Environmental Law, (1st Ed), Yogyakarta : Genta Press. 